\title{
Constitutionalization by Association? The Doubtful Case of the European Economic Area
}

\author{
Thomas Burri* and Benedikt Pirker**
}

\section{Introduction}

The European Economic Area (EEA) is a special form of association created initially for all the European Free Trade Area (EFTA) countries which were looking for a way to strengthen their economic ties with the European Union's (EU) single market without abandoning their sovereignty to the extent of joining the EU to become a Member State. The EEA Agreement aims to reconcile the logics of integration and of preservation of sovereignty using tools of international law to prevent on the one hand the transfer of legislative powers and sovereignty of the EFTA EEA States and to create on the other hand a complex dynamic legal regime; this legal regime encompasses the constant adaptation of EEA law to new relevant legislation adopted in the $\mathrm{EU}$ and the homogeneous interpretation of legal provisions identical to norms of the Treaty on the Functioning of the European Union (TFEU), referring for this latter purpose to the case-law of the Court of Justice of the European Union (CJEU).

The academic discussion on the 'constitutionalization' of EU law has become rich over the years; however, to date the debate largely left out the development of the EEA, treating it, in a sense, as the less valuable creation. We aim to fill this lacuna with the present contribution. ${ }^{1}$

We start with a summary assessment of the operation of EEA law for readers less familiar with the EEA (second section). The following section examines the notion of constitutionalization in order to assess the state of

\footnotetext{
* Assistant Professor of International and European Law at the University of St. Gallen (HSG).

** Post-doctoral assistant, University of Fribourg. The authors would like to thank Daniel Halberstam and the two anonymous reviewers for insightful comments on earlier versions of this paper.

1 The EEA as such covers all EU Member States as well; however, for the latter it is an integral part of EU law and interpreted by the Court of Justice of the European Union (see Section II). For the present contribution, we focus on the EEA and its institutions as set up for the EFTA EEA Statesthe constitutional dimension that EEA law as a legal regime of its own has reached.
} 
constitutionalization of EEA law. Beyond constitutional functions the notion also implies a role for the concept of autonomy. With this in mind, we embark on a journey through various features of EEA law. A commentator on the negotiating process of the EEA Agreement once coined the phrase that the EEA was 'an attempt to mix oil and vinegar.'. Similar to this assessment, we discover in a fourth section that there are a number of constitutional functions present in substantive EEA law which have been transposed from the EU legal context; but, as the fifth section shows, there are also institutional limitations of the EEA which lead to the conclusion that EEA law is hardly constitutionalized at all. Indeed, we conclude that here the oil can be distinguished from the vinegar.

\section{The Legal Regime of the European Economic Area Revisited}

The European Economic Area is a special legal mechanism created to integrate the EFTA Member States ${ }^{3}$ into large parts of the internal market while excluding other selected areas of cooperation of the EU Treaties. It is based on a mixed agreement concluded in the form of a multilateral association agreement encompassing a wide range of topics. ${ }^{4}$ As set out in Article 1 of the EEA Agreement, ${ }^{5}$ the central objective is the creation of a 'homogeneous European Economic Area', which should encompass the free movement of goods, persons, services, and capital, the 'setting up of a system ensuring that competition is not distorted and that the rules thereon are equally respected', as well as close cooperation in fields such as research and development, the environment, education, and social policy.

Homogeneity across all the EEA (ie including EU and EFTA EEA States) is to be achieved through a particular institutional setting. The functioning of the

\footnotetext{
2 Sven Norberg, quoted in K Almestad, 'The Squaring of the Circle - The Internal Market and the EEA' in M Johansson and others (eds), A European for All Seasons - Liber amicorum in Honour of Sven Norberg (Bruylant, 2006), p 1 at p 2.

3 Of the EFTA States, only Norway, Iceland, and Liechtenstein are members of the EEA. Switzerland rejected the EEA Agreement in a negative referendum in 1992, while Austria, Finland, and Sweden joined the EEA in 1994 only to accede in 1995 to the EU. See nonetheless on the legal effects of EEA law during this brief period with the example of Sweden U Bernitz, 'The Application of EEA Law in Sweden' in M Monti, N Von und Zu Liechtenstein and B Versterdorf (eds), Economic Law and Justice in Times of Globalisation - Festschrift for Carl Baudenbacher (Nomos, 2007), p 29.

${ }^{4}$ See on the need for a mixed agreement concluded both by the EU and the Member States because of certain aspects of intellectual property rights covered by the EEA T Cottier, 'Der Schutz des geistigen Eigentums im Europäischen Wirtschaftsraum' in O Jacot-Guillarmod (ed.), Accord EEE-Commentaires et réflexions (Schulthess, 1992), p 411 at p 415. See more broadly on different categories of association agreements based on their content A Epiney, Der Stellenwert des europäischen Gemeinschaftsrechts in Integrationsverträgen : $z u$ den Möglichkeiten der Übernahme des Gemeinschaftsrechts in ,Integrationsrecht' unter besonderer Berücksichtigung des EWR (Schulthess, 1992), p $55 \mathrm{ff}$.

5 [1994] OJ L 1, p 3.
} 
EEA as a homogeneity-producing legal regime becomes easier to grasp, when its operation is looked on as a sequence. Homogeneity as the central objective of the EEA is pursued by a complex process of interaction between the various players: the EEA Agreement transposes provisions of EU primary law in identical wording to the EEA context, while the annexes of the Agreement perform the same function in the form of references to EU secondary legislation. ${ }^{6}$ At the same time, these references are updated and adapted to new developments in the EU by decisions of the EEA Joint Committee as the 'legislature'. To prevent difficulties with the constitutional systems of the EFTA EEA States, the EEA Agreement clarifies, however, expressly that no legislative powers are transferred to the EEA institutions. ${ }^{7}$ Article 7 EEA Agreement obliges the EFTA EEA States to transpose the secondary legislation contained in the annexes to the EEA Agreement—often referred to as 'mirror legislation'8_-into their legal orders.

In this quasi-legislative procedure, the institutional setting only partly mirrors that of the EU. As with most association agreements, a central role is played by the Joint Committee. The prerogatives of the EEA Joint Committee encompass surveillance of the implementation of the agreement, the settlement of disputes, and - centrally - the transposition of new EU legislative acts in the EEA context. ${ }^{10}$ The EEA Council as a political institution only lays down 'general guidelines' for the EEA Joint Committee, ${ }^{11}$ while the Joint Parliamentary Committee has merely consultative functions. ${ }^{12}$

Once EEA law is in place other institutions are charged with the surveillance of its respect and its interpretation. In conjunction with the EEA Agreement the EFTA EEA States also signed an Agreement on the establishment of a Surveillance Authority and a Court of Justice (SCA). ${ }^{13}$ Similar to the EU Commission, the Surveillance Authority has the tasks to enforce the competition rules of the EEA Agreement in the EFTA EEA States and to ensure that these States fulfil their obligations and respect EEA law. ${ }^{14}$

The EFTA Court was set up to adjudicate in four types of direct actions: infringement actions brought by the Surveillance Authority against an EFTA

${ }^{6}$ T Blanchet and others, The Agreement on the European Economic Area (EEA) - A Guide to the Free Movement of Goods and Competition Rules (Clarendon Press, 1994), p 22; note that the reference technique was indispensable to avoid the inclusion of about 1,700 legislative acts into the text of the EEA Agreement.

7 See preamble to Protocol 35 of the EEA Agreement.

8 C Baudenbacher, 'Between Homogeneity and Independence: The Legal Position of the EFTA Court in the European Economic Area' (1996-97) 3 Columbia Journal of European Law 169 at 176.

${ }^{9}$ Art 7 EEA Agreement distinguishes between acts corresponding to a regulation and acts corresponding to a directive, leaving more discretion for domestic implementation in the latter case, as under EU law.

${ }^{10}$ See concisely Blanchet and others, above n 6, p 27.

${ }_{11}$ Art 89 EEA Agreement.

12 Art 95 EEA Agreement.

13 [1994] OJ L 344, p 3.

14 Art 5(1) SCA. 
EEA State, settlement of disputes between EFTA EEA States, actions against the Surveillance Authority, and actions for annulment of decisions taken by the Surveillance Authority. ${ }^{15}$ More important in practice than these four actions are, however, requests for advisory opinions under Article 34 SCA as an additional way of addressing the EFTA Court. ${ }^{16}$ Based on their constitutional traditions the Nordic countries had substantial difficulties to submit judiciary functions to any international court. As a consequence, while the procedure follows in its spirit that of a reference for a preliminary ruling in EU law, in fact neither are advisory opinions given by the EFTA Court binding on national courts nor is there an obligation to submit a request for the highest domestic courts where they are uncertain how to interpret EEA law. ${ }^{17}$ The CJEU furthermore insisted in two opinions given on the EEA Agreement before its signature that a strict two pillar-separation had to be accepted, in the sense that there could be no EEA Court common to all EEA States (ie EU and EFTA EEA States) where CJEU judges and EFTA States' judges would sit together and interpret EEA law for all EEA States or where the EEA Court could influence with its interpretations the reading of EU law and the scope of competences under EU law. ${ }^{18}$

Direct actions are thus broadly comparable in their operation to their counterparts in EU law. ${ }^{19}$ The framework of the judiciary is, however, incomplete, because there is no constraining mechanism that ensures one uniform authoritative interpretation of EEA law for the EFTA EEA States and that is of

15 DT Björgvinsson, 'Application of Article 34 of the ESA/Court Agreement by Icelandic Courts' in M Monti and others (eds), Economic Law and Justice in Times of Globalisation - Festschrift for Carl Baudenbacher (Nomos, 2007), p 37.

16 See T Örlygsson, 'Iceland and the EFTA Court - Twelve Years of Experience' in M Monti and others (eds), Economic Law and Justice in Times of Globalisation - Festschrift for Carl Baudenbacher (Nomos, 2007), p 225 at pp 230-1.

17 See Art 34 SCA; Björgvinsson, above n 15, p 38.

18 See CJEU 14 December 1991, Opinion 1/91 Draft agreement between the Community, on the one hand, and the countries of the European Free Trade Association, on the other, relating to the creation of the European Economic Area and CJEU 10 April 1992, Opinion 1/92 Draft agreement between the Community, on the one hand, and the countries of the European Free Trade Association, on the other, relating to the creation of the European Economic Area. See for a concise summary of the opinions $\mathrm{HH}$ Fredriksen, 'One Market, Two Courts: Legal Pluralism vs. Homogeneity in the European Economic Area' (2010) 79 Nordic Journal of International Law 481 at 482. See also in this context the more recent opinion handed down by the CJEU 8 March 2011, Opinion 1/09 Draft agreement on the Creation of a unified patent litigation system (European and Community Patents Court), paras 74-76 and 80 . The Court confirmed in that case that the EU could submit itself to a court created by an international agreement as part of its external competences; according to the CJEU, there could even be a European Patent Court capable of referring preliminary questions to the CJEU. However, the exclusion of national courts from their role as 'ordinary' courts capable of referring questions to the CJEU in the area of patents was an inacceptable alteration of the 'essential character' of the distribution of powers under the Treaties (para 89).

${ }^{19}$ See also on the problems of legal standing in the case of actions for annulment for individuals which are comparable to EU law: EFTA Court 19 June 2003, Case E-2/02 Technologien Bau- und Wirtschaftsberatung GmbH and Bellona Foundation v Norway, para 39. 
comparable force to that of the CJEU in EU law. ${ }^{20}$ The EEA Agreement being an integral part of EU law, it is interpreted by the CJEU for the EU Member States. ${ }^{21}$ For EFTA EEA States in principle the EFTA Court can answer questions on the interpretation of EEA law, but its interpretative authority is somewhat weaker because of the advisory nature of the opinion procedure.

The EFTA Court is, however, also constrained in its interpretation of EEA law by the objective of homogeneity. Homogeneous interpretation of EEA law in light of EU law is ensured by Article 6 EEA Agreement which requires the EFTA Court to follow the 'relevant' case-law issued by the CJEU before the signature of the EEA Agreement. ${ }^{22}$ For all later case-law, the EFTA Court is obliged by Article 3(2) SCA to 'pay due account to the principles laid down' by the CJEU. Beyond these express provisions addressed at the EFTA Court, there is also a duty of surveillance for the EEA Joint Committee of the development of the case-law under both pillars ${ }^{23}$ and a system of information exchange on case-law between the courts. ${ }^{24}$ If there still emerges a divergence in the interpretation of identical provisions in EU and EEA law, the EEA Joint Committee can submit a question to the CJEU. ${ }^{25}$

Homogeneity thus extends throughout the 'life' of EEA law from its creation via its interpretation to its implementation. With this elaborate institutional scenario in mind, it comes as no surprise that a largely homogeneous legal situation throughout the EEA has effectively been achieved. There are, however, some features of EEA law that distinguish it from EU law; these stem from the willingness of EFTA EEA States to combine integration into the single market with the maintenance of their sovereignty. As a result of that, EEA law in some instances resembles more international law than the supranational law of the EU. The weaker position of the EFTA Court has already been noted; but there is also no direct effect or supremacy of EEA law in the same sense as in EU law. ${ }^{26}$

An inquiry into the 'constitutional' character of the EEA must thus necessarily account for the substantive convergence between EEA law and EU law, but also for the institutional differences between the two legal orders. A closer discussion of the notion of 'constitutionalization' shows that its content can accommodate these two diverging narratives through the introduction of the

\footnotetext{
${ }^{20}$ See for the claim to complete the incomplete setting of judicial remedies with a preliminary ruling procedure S Magnússon, 'On the Authority of Advisory Opinions' (2010) 13 Europarättslig tidskrift 528 at 535-6.

${ }_{21}$ CJEU 15 June 1999, Case C-321/97 Andersson and Wåkerås-Andersson, paras 27-28.

22 The date of signature is 2 May 1992.

23 Art 105(2) EEA Agreement. Note that it has become common to speak of two pillars with regard to the EEA: an EEA EFTA pillar which concerns the EEA EFTA States (and which is monitored by the EFTA Surveillance Authority and the EFTA Court) and an EEA pillar which concerns the EU States (and which is monitored by the regular EU institutions, ie the Commission and the CJEU).

${ }_{24}$ Art 106 EEA Agreement.

25 Art 111(3) EEA Agreement.

26 See on this point Section V.B.
} 
concept of autonomy. This latter notion usefully informs our subsequent detailed assessment of constitutional functions and constitutionalization in EEA law.

\section{Constitutions, Constitutional Functions, and Constitutionalization}

Constitutionalization is the 'grand narrative' in the scholarly literature on European integration. ${ }^{27}$ However, in light of the two divergent narrativessubstantial homogeneity, institutional diversity-present in the EEA context in comparison to EU law, a closer look at the notion of constitutionalization is required.

The rather classic approach to an inquiry into the process of constitutionalization of a legal regime such as EU law would base itself on constitutional functions such as the distribution of competences or the protection of fundamental rights. Various commentators described the European Union and European Union law as a constitutional regime based on findings that constitutional functions are to some extent exercised at the level of the EU and its institutions. $^{28}$

A more complex account is suggested with the introduction of the concept of autonomy as part of the process of 'constitutionalization'. In a recent contribution, Möllers defines 'constitutionalization' as the 'developing autonomy of international regimes from intergovernmental action'. ${ }^{29}$ This notion can apply as much to EU law as to EEA law and is part and parcel of our assessment. ${ }^{30}$ However, a focus on autonomy in this sense also implies subtle criticism of classic assessments of constitutionalization.

In Möllers' view, a mere assembly of constitutional functions does not necessarily lead to the conclusion that a legal regime is a constitution or 'constitutional'. Next to their 'constitutive' function, constitutions possess a 'legitimizing' function. A European constitution, in order to fulfil such a legitimizing function, would thus have to ensure the autonomy of the European citizens in the form of democratic self-determination through effective possibilities of participation in the political process. This is, however, according to Möllers the point where a narrative focusing merely on parallels of

27 A Stone Sweet, 'The European Court of Justice', in P Craig and G De Búrca (eds), The Evolution of EU Law (Oxford University Press, 2011), p 121 at p 132.

${ }^{28}$ See eg at an early stage J Schwarze, 'Verfassungsentwicklung in der Europäischen Gemeinschaft' in J Schwarze and R Bieber (eds), Eine Verfassung für Europa : von der Europäischen Gemeinschaft zur Europäischen Union (Nomos, 1984), p 15 at p 25 or A Peters, Elemente einer Theorie der Verfassung Europas (Duncker \& Humblot, 2001), p $234 \mathrm{ff}$.

29 C Möllers, 'Pouvoir Constituant - Constitution - Constitutionalisation' in A von Bogdandy and J Bast (eds), Principles of European Constitutional Law (Hart, 2010), p 169 at p 195.

30 See Section V.B. 
constitutional functions being exercised at the EU level reaches its limits. Such a narrative can merely support the function of allocation of power as a constitutional function; this functional perspective provides, however, only a description of the status quo of integration. Such function-picking and choosing does not explain the systemic dependency of the EU model upon the pre-existence of the Member States and the failure of the European constitution to systematically address the EU citizen directly and not through the collectivity of his or her Member State. There is a 'complex relationship' between the European institutions, Member States, and the rights of citizens which should not be covered up by a discussion limited on an assessment of single, hand-picked constitutional functions. ${ }^{31}$

We draw two central observations from Möllers' views for our assessment of the state of constitutionalization of the EEA. Both are based on the concept of autonomy, but with a different rationale. ${ }^{32}$ First, a finding of functions that could be labelled 'constitutional' may indeed serve as an indication for a process of constitutionalization. However, EEA law does not automatically become a constitutional regime because of such features. The incompleteness of constitutional transformations must be kept in the picture, in particular as far as such incompleteness concerns decision-making processes that are unsatisfactory from the point of view of democratic self-determination of individuals as 'EFTA EEA citizens'. We could term this the 'citizen dimension' of autonomy. Second, constitutionalization is a development towards autonomy of one legal regime. We must thus also take into account to what extent EEA law has become an independent legal regime, one autonomous from international law, from EU law, and from the domestic legal orders of the EFTA EEA States in its legal effect and its interpretation. Hence, autonomy also possesses a 'regime dimension'. The present inquiry distinguishes thus between substantive law with inherent constitutional functions of EEA law and institutional features of EEA law which reveal the limits of the process of constitutionalization. It is in particular in the fifth section that the two dimensions of autonomy mentioned will play a crucial role.

\section{Constitutional Functions of EEA Law}

The substantive law of the EEA shows a high degree of homogeneity with its mirror law under the EU Treaties. To a remarkable extent, homogeneity proved to be an open floodgate for constitutional developments of EU law to enter EEA law. EEA law imitated EU internal market law in its power-allocating

\footnotetext{
31 Möllers, above n 29, pp 180-1.

32 When autonomy does not serve to stratify 'constitutionalization', but rather is considered on its own, in the perspective of minority protection a different, perhaps more nuanced conception of autonomy is required: T Burri, Models of Autonomy? (Schulthess, 2010), p $33 \mathrm{ff}$.
} 
jurisprudence which limits Member States' competences and regulatory powers for the benefit of economic integration. The case-law of the EFTA Court also aims to protect and respect fundamental rights. Finally, recent case-law extended the concept of citizenship from EU law to EEA law, raising the question whether there is a parallel 'EEA citizenship' next to Union citizenship.

\section{A. Power Allocation and Restrictions on EFTA EEA States' Regulatory Powers}

EEA law substantially mirrors Treaty provisions and secondary legislation in the field of the EU internal market. Based on the principle of homogeneity, the EFTA Court essentially replicated the CJEU's findings in its reading of the pertinent provisions. As but one example, in Nille, the EFTA Court cited a variety of internal market cases to construe Articles 11 and 13 of the EEA Agreement parallel to Articles 34 and 36 TFEU which contain the central prohibition on quantitative restrictions on the free movement of goods and measures having equivalent effect and the express derogations from this prohibition. It even transplanted the CJEU's distinction between product requirements and selling arrangements stemming from the Keck jurisprudence to the EEA context. ${ }^{33}$ Similar to EU Member States, the EFTA EEA States are thus precluded from regulating in a manner that creates unnecessary barriers to trade.

Homogeneity played a central role in this process of approximation. Not only could the EFTA Court draw from the CJEU's rich jurisprudence to construe the EEA Agreement's parallel provisions, but also a fruitful judicial dialogue developed between the two institutions. The CJEU also profited from this dialogue, taking on occasions inspiration from the EFTA Court and even adopting the latter's conclusions for similar cases which had been answered previously by the EFTA Court. ${ }^{34}$

Beyond building bridges between courts, the principle of homogeneity could even achieve building bridges 'in time' in the internal market. The continuous amendment of the EU Treaties during the 1990s posed the challenge that the EEA Agreement could not follow these various changes in the Treaty text. Based on homogeneity, the EFTA Court, however, managed to elude obstacles of an

\footnotetext{
33 EFTA Court 14 May 1997, Case E-5/96 Ullensaker kommune and others v Nille AS, paras 33-34.

${ }^{34}$ As an example the principle of precaution's role in internal market cases had been substantially developed by the EFTA Court in EFTA Court 5 April 2001, Case E-3/00 EFTA Surveillance Authority $v$ Norway, para 73. Faced with a similar question, the CJEU could largely base its answer on the EFTA Court's findings, see CJEU 23 September 2003, Case C-192/01 Commission $v$ Denmark, para 49. See more closely on this process and for other examples C Baudenbacher, "The EFTA Court, the ECJ, and the Latter's Advocates General - a Tale of Judicial Dialogue' A Arnull, P Eeckhout and T Tridimas (eds), Continuity and Change in EU Law - Essays in Honour of Sir Francis Jacobs (Oxford University Press, 2008), p 90 at p 95. See also C Timmermans, 'Creative Homogeneity' in M Johansson and others (eds), A European for All Seasons - Liber amicorum in Honour of Sven Norberg (Bruylant, 2006), p 471.
} 
outdated Treaty text. ${ }^{35}$ The provisions on the free movement of capital provide a good example. The EFTA Court ignored that by contrast to the then current version of the European Community Treaty ${ }^{36}$ the EEA Agreement did not set out express justifications for States' measures derogating from the free movement of capital for public purposes and admitted such justifications. ${ }^{37}$

The substantive provisions of EEA law, which restrict the regulatory powers of EFTA EEA States for the benefit of economic integration, combined with the decision-making procedure set out in the EEA Agreement ${ }^{38}$ constitute thus a mechanism of power allocation, which restrains the use of certain powers of States. The principle of homogeneity supported the transfer of this power-allocation mechanism-which had originally been developed in the context of the EU-from the EU to the EEA.

\section{B. Fundamental Rights in the EEA Legal Order}

The respect of fundamental rights grew incrementally in importance over the years in EU law. ${ }^{39}$ The CJEU introduced fundamental rights as part of the general principles of EU law, drawing inspiration from the constitutional traditions of the EU Member States for this purpose and earning much praise for introducing this constitutional aspect into its case-law. ${ }^{40}$

A substantially homogeneous legal order such as the EEA was likely to raise similar concerns on the respect of the fundamental rights of individuals. Recognition of fundamental rights took, however, a different road than in the EU.

As a starting point, the textual basis continues to be meagre in comparison. While in EU law, the commitment to respect fundamental rights developed over the years into the solid codification of Article 6 TEU, ${ }^{41}$ the EEA Agreement features the respect of fundamental rights only in its preamble, where the

35 D Buschle, 'The Free Movement of Capital in the EEA - A Lehrstück in Homogeneity' in M Monti and others (eds), Economic Law and Justice in Times of Globalisation - Festschrift for Carl Baudenbacher (Nomos, 2007), p 75 at pp 94-5.

36 Today's Art 65 TFEU.

37 EFTA Court 1 July 2005, Case E-10/04 Paolo Piazza v Paul Schurte AG, para 39.

38 See on the latter Section V.A.

39 See for an overview eg G. De Búrca, 'The Evolution of EU Human Rights Law' in P Craig and G De Búrca (eds), The Evolution of EU Law (Oxford University Press, 2011), p 465.

40 See the classic CJEU 17 December 1970, Case 11/70 Internationale Handelsgesellschaft. See for such praise eg T Tridimas, 'Primacy, Fundamental Rights and the Search for Legitimacy' in MP Maduro and L Azoulai (eds), The Past and Future of EU Law - The Classics of EU Law Revisited on the 50th Anniversary of the Rome Treaty (Hart Publishing, 2010), p 98 at p 103, who speaks even of the CJEU as a 'Supreme Court of the EU'. See also Opinion of Advocate General Sharpston, 30 September 2010 Ruiz Zambrano, paras $82 \mathrm{ff}$ on the role of fundamental rights in the EU legal order.

41 See in particular Art 6(3) TEU: 'Fundamental rights, as guaranteed by the European Convention for the Protection of Human Rights and Fundamental Freedoms and as they result from the constitutional traditions common to the Member States, shall constitute general principles of the Union's law.' 
'contribution that a European Economic Area will bring to the construction of a Europe based on peace, democracy and human rights' is emphasized. Still, good arguments can be made in favour of respect of fundamental rights. Apart from the reference in the preamble, homogeneity with EU law also supports taking into account the protection of fundamental rights. Furthermore, in a 1992 declaration the EEA parties emphasized the continuing effect of rights and obligations under earlier international agreements, which include the European Convention on Human Rights. ${ }^{42}$

Although no formal priority of the European Convention on Human Rights over the EEA Agreement can be derived from the general rules on a potential conflict of norms in international law, ${ }^{43}$ the EFTA Court effectively referred to the rights of the Convention and the European Court of Human Rights' case-law in a number of cases.

Some of these references have remained rather cursory. As an example, in $T V$ 1000 Sverige the EFTA Court referred to the European Court of Human Rights' findings in the Handyside case ${ }^{44}$ on the possibility of restricting the freedom of expression - here for broadcasting operators-based on the protection of minors as a legitimate policy objective and the need for deference to the findings of a Member State, as had already been confirmed previously in the case-law of the CJEU. ${ }^{45}$ More emphatically, in Ákeruvaldid v Ásgeir Logi Ásgeirsson and others the EFTA Court held that provisions of EEA law generally had to be 'interpreted in the light of fundamental rights' of the European Convention on Human Rights, and that the Convention's provisions as well as the European Court of Human Rights' jurisprudence were 'important sources' to determine the content of rights under EEA law. ${ }^{46}$

The EFTA Court thus certainly aims to ensure the respect of fundamental rights based on the standards enshrined in the European Convention on Human Rights, without, however, clarifying exactly what legal base it is drawing on for this purpose. A scholar suggested that following the model of the CJEU, the EFTA Court adjudicated based on Convention rights as 'part of the general unwritten principles of EEA law'. ${ }^{47}$ While the effect may be the same, in

42 W Kälin, 'EWR Abkommen und Europäische Menschenrechtskonvention' in O Jacot-Guillarmod (ed), Accord EEE - Commentaires et reflexions (Schulthess, 1992), p 653 at p 661.

43 See on this point Kälin, above n 42, pp 659-60.

${ }_{44}$ ECtHR 7 December 1976, Case No 5493/72 Handyside v United Kingdom.

45 EFTA Court 12 June 1998, Case E-8/97 TV 1000 Sverige AB v Norway, para 26. In Bellona Foundation v Norway, above n 19, para 37, the EFTA Court even more summarily referred only to the 'idea of human rights' which would support an expansion of the access to justice while the Court was discussing the limited legal standing for individuals in direct actions aimed at the annulment of EEA legal acts.

46 EFTA Court 12 December 2003, Case E-2/03 Ákaruvaldið (The Public Prosecutor) v Ásgeir Logi Ásgeirsson, Axel Pétur Ásgeirsson and Helgi Már Reynisson, para 23. See also EFTA Court 28 June 2011, Case E-12/10 EFTA Surveillance Authority v Iceland, para 60.

47 DT Björgvinsson, 'The EEA Agreement and Fundamental Rights' in L Caflisch and others (eds), Human Rights - Strasbourg Views - Liber amicorum Luzius Wildhaber (Engel, 2007), p 25 at p 38. 
practice one can observe a remarkable avoidance by the EFTA Court to explicitly embrace the concept of general principles for this purpose. Even in the recent Clauder case, the EFTA Court repeated its findings in Asgeirsson, emphasizing that all EEA States were parties to the European Convention on Human Rights and that the right to respect for private and family life at issue was both enshrined in the Convention as well as in Article 7 of the EU Charter of Fundamental Rights; but although this process of assessing the status of a fundamental right through looking into various other legal orders resembles the process of the CJEU in recognizing general principles of EU law, the EFTA Court did not mention such principles expressly at any point. ${ }^{48}$ The EFTA Court neither stated that Convention rights were the one and exclusive source of fundamental rights standards, nor did it by contrast expressly take into account the codification of fundamental rights in constitutional law of EFTA EEA States in its assessment. ${ }^{49}$

Despite such methodological differences in reaching a result, the EFTA Court concludes similarly to the CJEU that in the EEA legal order fundamental rights must be respected. This further constitutional function is thus also clearly present in EEA law.

\section{EEA Citizenship}

The concept of EU citizenship was introduced by the Treaty of Maastricht into EU law. Soon discovered by the CJEU, it became the basis of a paradigmatic change in EU law which complemented an essentially purely market-based paradigm of integration with a strong component of policy integration. ${ }^{50}$ The CJEU found that citizenship constituted the new 'fundamental status' of nationals of EU Member States, ${ }^{51}$ and created in its case-law based on the general prohibition of discrimination based on nationality a broad entitlement to equal treatment for EU citizens in a variety of situations which went beyond the rather economic context of internal market freedom cases. ${ }^{52}$ More generally, citizenship also brings with it a right to move and reside freely within the territory of

48 EFTA Court 26 July 2011, Case E-4/11 ArnulfClauder, para 49. See for a similar view based on previous case-law Fredriksen, above n 18, p 492.

49 EFTA Surveillance Authority $v$ Iceland, above n 46, para 60.

50 B De Witte, 'Direct Effect, Primacy, and the Nature of the Legal Order' in P Craig and G De Búrca (eds), The Evolution of EU Law (Oxford University Press, 2011), p 323 at p 359.

51 CJEU 20 September 2001, Case C-184/99 Grzelczyk $v$ Centre public d'aide sociale d'Ottignies-Louvain-La-Neuve, para 31.

52 See for references to the case-law J Shaw, 'Citizenship: Contrasting Dynamics at the Interface of Integration and Constitutionalism' in P Craig and G De Búrca (eds), The Evolution of EU Law (Oxford University Press, 2011), p 575 at p 586. See, concerned about the ever-expanding case-law of the CJEU, NN Shuibhne, 'The Outer Limits of EU Citizenship: Displacing Economic Free Movement Rights?' in C Barnard and O Odudu (eds), The Outer Limits of European Union Law (Hart, 2009), p 167 at pp 194-5. Indeed, citizenship case-law extended even to the very question of conferral and loss of Member State nationality as the link to EU citizenship, see CJEU 2 March 2010, Case C-135/08 Rottmann and for a more detailed discussion T Burri and B Pirker, 'Commentaire sur 
EU Member States, whose conditions and details are set out in Directive 2004/ 38/EC. This directive was subsequently also transposed to the EEA context. ${ }^{53}$

The weight given to the concept of citizenship became particularly visible in the CJEU's case-law on the right to reside and the right of EU citizens to family life under this directive. The right of residence for more than three months is subject to conditions for EU citizens other than workers, self-employed persons, or students; EU citizens must have 'sufficient resources for themselves and their family members not to become a burden on the social assistance system of the host Member State during their period of residence' and have 'comprehensive sickness insurance cover. ${ }^{5}$ 'Family members 'accompanying or joining' the EU citizen can derive a right of residence for themselves from the right of that $\mathrm{EU}$ citizen as long as the EU citizen fulfils the conditions just set out. ${ }^{55}$

As an example for the integrationist tendency of the case-law on citizenship, in Metock the CJEU held that the possibility of family members 'joining' a EU citizen had to be interpreted broadly in the light of the right to family life enjoyed by each EU citizen under the directive. There could be no requirement for a citizen to already have founded a family when moving to a host Member State; even after the exercise of the right of freedom of movement, family members (typically third country nationals) could join the citizen and derive a right of residence from his right. ${ }^{56}$

In Clauder, the EFTA Court adopted a similar, citizen-friendly reading of the directive's conditions in the EEA context. Mr Clauder, a German national with a permanent residence permit in Liechtenstein, received old-age pensions from Germany and Liechtenstein and supplementary benefits because of the modest amount of these pensions. After getting married to a German national, $\mathrm{Mr}$ Clauder applied for family reunification, but was denied his request because his supplementary benefits would be increased if he was joined by his spouse. The reason for this denial was that he did not fulfil the requirement of having sufficient resources to be able to claim a derived right of residence for his wife under Article 7(1) d of Directive 2004/38/EC. Asked for an advisory opinion by the Liechtenstein Administrative Court, the EFTA Court emphasized that the directive ought not to be interpreted restrictively in light of its objective to promote the right of EEA nationals to move and reside freely within the territory of the EEA States and that the protection of family life had been recognized even before the adoption of the directive as an indispensable means to ensure

l'arrêt du 2 mars 2010 Rottmann, Affaire C-135/08, (non encore publié au Recueil)' (2010) Revue du droit de l'Union européenne 651.

53 See Directive 2004/38/EC of the European Parliament and of the Council of 29 April 2004 on the right of citizens of the Union and their family members to move and reside freely within the territory of the Member States ([2004] OJ L 258, p 77), as adapted to the EEA Agreement by EEA Joint Committee Decision No 158/2007 of 7 December 2007.

${ }^{54}$ Art 7(1)b of Directive 2004/38/EC.

55 Art 7(1)d of Directive 2004/38/EC.

56 CJEU 25 July 2008, Case C-127/08 Metock and others, paras 87-88. 
that the fundamental freedoms guaranteed under the EEA Agreement could effectively be exercised. ${ }^{57}$ The EFTA Court then held that the right to permanent residence as set out in Article 16 of the directive as the 'highest level of integration' in a host State necessarily included a right to live with one's family, ie a derived — not autonomous — right of residence had to be granted to a family member. ${ }^{58}$ As the condition of sufficient resources no longer applies to EEA citizens with a permanent right of residence, this condition should also not apply to a derived right for a family member, in particular since Directive 2004/38/EC expressly removed the general requirement for sufficient resources that had been present in earlier legislation. ${ }^{59}$ To preclude an EEA national from founding a family in his host State would thus impair his right to move and reside freely, and run counter to the objective of the directive and deprive it of its 'full effectiveness'. ${ }^{60}$ An interpretation in the light of fundamental rights supported this conclusion according to the EFTA Court. ${ }^{61}$

A highly remarkable feature of this case is the insistence by the EFTA Court on giving full effectiveness to the directive and to not allow anything to run counter to its broad objective. This vigorously teleological approach seems central to achieve a result in line with EU citizenship case-law for the purpose of achieving homogeneity, although the Court does not openly state so. Teleological interpretation enabled the EFTA Court to overcome the lack of a clear legal basis for EEA citizenship in the EEA Agreement itself which would give such citizenship comparable authority to citizenship under EU law. ${ }^{62}$

As a point of concern, similar to the CJEU's case-law on citizenship, the EFTA Court discussed insufficiently in its reasoning what values were actually in the balance: the value of free movement for EEA citizens is subjected to conditions in Directive 2004/38/EC because of the need to ensure solidarity among a given community; the conditions aim to ensure that no burden is imposed on the social system of a host State without the existence of a sufficient, effective link with that State. ${ }^{63}$ Despite the welcome outcome of the case, the strong reliance on teleological interpretation clouds the argumentation of the EFTA Court, which mirrors the sometimes excessive reliance on proportionality in the CJEU's citizenship jurisprudence. ${ }^{64}$

\footnotetext{
Clauder, above n 48, paras 33-34.

8 Clauder, above n 48, para 43.

59 Clauder, above n 48, paras 47-48.

${ }^{60}$ Clauder, above n 48, para 46.

${ }^{61}$ Clauder, above n 48, para 49.

62 See in particular Art 20 TFEU.
}

63 See on this point M Ross, 'The Struggle for EU Citizenship: Why Solidarity Matters' in A Arnull and others (eds), A Constitutional Order of States? - Essays in Honour of Alan Dashwood (Hart Publishing, 2011), p 283 at p 286.

${ }^{64}$ See with concerns on legal certainty in the EU context M Dougan, 'Expanding the Frontiers of European Union Citizenship by Dismantling the Territorial Boundaries of the National Welfare States?' in C Barnard and O Odudu (eds), The Outer Limits of European Union Law (Hart Publishing, 2009), p 119 at p 162. 
Yet, there is 'EEA citizenship'. Even though the EEA Agreement does not provide in a prominent manner for the concept, the EFTA Court in Clauder clearly laid the substantive foundations for a comprehensive right to move and reside freely granted to all citizens of EEA countries by means of a teleological interpretation of Directive 2004/38/EC, which is also likely to have an impact on future CJEU case-law. ${ }^{65}$

\section{Conclusion}

Summing up these findings, the substantive law of the EEA seems to lend itself to a comparison with EU law and merit the title of constitutionalization no less than EU law. Within the EEA legal order, there is allocation of powers as a constitutional function. There is protection of fundamental rights of EEA citizens. There is also an emerging concept of citizenship of the EEA, with certain rights linked to it which go beyond a paradigm of mere economic integration. But to accept such substantive features as a sign of a constitutional regime would mean making the mistake identified earlier of relying on mere hand-picked constitutional functions without taking into account institutional features. The seemingly clear case for EEA law as a constitutionalizing regime loses its sharp contours observed through the prism of autonomy. A number of institutional features of EEA law put the findings of this section in perspective.

\section{Limits to the Constitutionalization Narrative}

For a full picture of the 'constitutionalization' of the EEA, there must also be an account of the autonomy dimensions of 'constitutionalization'. We have previously distinguished a 'citizen dimension' and a 'regime dimension' of autonomy. This means that we must assess EEA law in light of the role of EFTA EEA citizens. The autonomy of citizens goes beyond subjective rights such as the right to move and reside freely discussed previously, and enshrines the dimension of citizens as participants in the law-making process-ie EFTA EEA citizens' right to self-determination as participants in a democratic constitutional system. At the same time, we also assess the autonomy of EEA law more literally as to whether EEA law is indeed autonomous as a legal regime from international law and from domestic law of the EFTA EEA States. As a further part of the 'regime dimension' of autonomy, it should be examined whether EEA law is independent in its interpretation or whether ultimately interpretation must necessarily follow the interpretation of parallel EU law because of the objective of homogeneity.

65 Note that in the Clauder case, the Netherlands and Denmark as well as the Commission decided to intervene to submit their observations. 


\section{A. The EEA Legislative Decision-making Process and the Role of EFTA EEA Citizens}

The previous analysis showed the shortcomings of 'constitutionalist' rhetoric in the assessment of the EU's decision-making process which does not necessarily account for the indirect representation of EU citizens through their respective Member State as necessary constituents of the legislative process. Transferring these thoughts to the context of the EEA, some even stronger concerns emerge on pulling a constitutional cloth over the EEA process of adapting EEA law to the current state of EU internal market law.

The overview of the EEA institutions noted the central role of the EEA Joint Committee which transposes new legislation into the EEA context by unanimous decision. ${ }^{66}$ The EFTA EEA States as well as their citizens are only very indirectly represented in this 'legislative' process $^{67}$ in the EEA; not only is there no room for any parliamentary assembly comparable to the European Parliament, but also the EU and the EFTA States as the two Contracting Parties each speak with only one uniform voice in the EEA Joint Committee for the purpose of decision-making. ${ }^{68}$

The legislative procedure as the process of transposition of EU law into the EEA context only minimally offsets this low degree of representation: in a first phase of so-called 'decision-shaping', EFTA EEA States have a consultative right of participation in the drafting process of new EU legislation. ${ }^{69}$ This minimal possibility to influence the content of legislation to be transposed later on is, however, complemented by high pressure in practice to adapt EEA law without delay to the situation prevailing in EU law in order to avoid disadvantages for EFTA EEA citizens. ${ }^{70}$

Decision-making in the EEA context is thus a process which leaves hardly any leeway for the EFTA EEA States to influence the content of legislation to be adopted. In the process, the view of an EFTA EEA citizen is represented only in a highly indirect fashion through his or her EFTA EEA State government which, moreover, is obliged to speak together with the other EFTA EEA State governments with one voice.

\footnotetext{
66 See Section II.

${ }^{67}$ It should, of course, be noted that at least formally, EFTA EEA States did not transfer legislative powers to the EEA institutions, as emphasized by Örlygsson, above n 16, p 228.

68 Art 93(2) EEA Agreement.

69 Arts $99 \mathrm{ff}$ EEA Agreement. See also more closely on the EEA legislative procedure S Norberg and others, The European Economic Area - EEA Law - A Commentary on the EEA Agreement (Fritzes, 1993), p 137ff.

70 A Entner-Koch, 'Liechtenstein im „EWR-Rechtsetzungsprozess“' in T Bruha, ZT Pállinger and R Quaderer (eds), Liechtenstein_10 Jahre im EWR_Bilanz, Herausforderungen, Perspektiven (Verlag der Liechtensteinischen Akademischen Gesellschaft, 2005), p 81 at p 88, underlines that in practice most legislative changes enter into force in the EEA EFTA States with a delay of only three to six months.
} 


\section{B. The Autonomy of the EEA Legal Order: Direct Effect, Primacy, and State Liability for Incorrect Implementation of EEA Law}

One of the main particularities of EU law which has also formed part of its constitutionalization narrative is its autonomy as a legal order, reached through the effect it unfolds within the legal orders of EU Member States. Based on 'the spirit, the general scheme and the wording' of the Treaty the CJEU provided EU law with direct effect ${ }^{71}$ and primacy, ${ }^{72}$ without leaving these questions to national law as would be the case with international law. ${ }^{73}$

The EEA Agreement is structured differently because of the need to respect the dualist constitutional traditions of the Nordic EFTA EEA States, who were reluctant to transfer legislative powers to the EEA institutions. ${ }^{74}$ Because of this reluctance, EEA law could not be vested with direct effect in a comparable way to EU law; in fact, some commentators suggested that the recognition of direct effect to EEA law by the EFTA Court would damage the legitimacy of the Court and could even mean the end of the EEA Agreement. ${ }^{75}$ Direct effect remains thus an issue which is decided by domestic law. ${ }^{76}$ Primacy, on the other hand, is expressly laid down in Protocol 35 of the EEA Agreement, which requires EFTA EEA States to introduce 'if necessary' a statutory provision in domestic law to ensure primacy of EEA law over domestic law in case of conflict. Again, however, matters are left to be regulated by the domestic legal order. ${ }^{77}$

While EU law has thus developed into a specific autonomous legal order with strong effect at the national level through the judicial introduction of primacy and direct effect, the EFTA Court turned out to be more reluctant. Still, it held that EEA law was to a large extent addressed to individuals and its proper functioning depended on individuals being able to rely on the rights conferred

71 CJEU 5 February 1963, Case 26/62 NVAlgemene Transport en Expeditie Onderneming Van Gend en Loos $v$ Nederlandse administratie der belastingen, 12. See in more detail De Witte, above n 50, pp 326-7.

72 CJEU 15 July 1964, Case 6/64 Costa v ENEL. See De Witte, above n 50, p 329.

73 This particularity of EU law is not recognized by all scholars as truly distinctive, see eg O Spiermann, 'The Other Side of the Story: An Unpopular Essay on the Making of the European Community Legal Order' (1999) 10 European Journal of International Law 763 for a more sceptical account. See also on the autonomy of the EU legal order the Court in European and Community Patents Court, above n 18, paras 75-76, emphasizing that the 'essential character of the function' of the Court is part and parcel of the 'autonomy of the European Union legal order', neither of which must be adversely affected, eg by the signature of an international agreement.

74 See Örlygsson, above n 16, p 228, who points out that Liechtenstein is the only country with a monist tradition.

75 Henrik Bull, cited in Fredriksen, above n 18, p 490 and fn 37.

76 See eg for a recent claim to give direct effect to EEA law in Icelandic law based on a comparison with the effect given to the European Convention on Human Rights ÓI Hannesson, 'The Status of Non-Implemented EEA Law in Iceland: Lessons from the Judicial Reactions of the Supreme Court to International Law' (2011) 80 Nordic Journal of International Law 425 at 458.

77 See on case-law confirming supremacy of EEA law in Liechtenstein and the statutory solutions found in Norway and Iceland Örlygsson, above n 16, pp 229-30. 
on them by the EEA Agreement. ${ }^{78}$ The EEA Agreement is thus in the EFTA Court's opinion an 'international treaty sui generis which contains a distinct legal order of its own', whose depth of integration is 'less far-reaching than' that under EU law, but which goes 'beyond what is usual for an agreement under public international law' in terms of its scope and objective. ${ }^{79}$ This declaration of autonomy sui generis by the EFTA Court did not entail direct effect of EEA law, but the possibility for individuals to claim liability of an EFTA EEA State for compensation for loss and damage caused by the incorrect implementation of EEA law. ${ }^{80}$

The autonomy of EU law is thus not mirrored in EEA law: EEA law trusts the national legal order to give legal force to EEA rights and obligations. Article 3 EEA Agreement contains a broad duty of cooperation under which EFTA EEA States have to take all appropriate measures to ensure fulfilment of their obligations under the EEA Agreement. Combined with the obligation to implement EU regulations and directives transferred to EEA law under Article 7 EEA Agreement and the obligation to ensure primacy of EEA law by statute, EFTA EEA States are thus in principle obliged to ensure that their domestic legal orders comply with EEA law and provide for the rights of individuals granted by EEA law. However, these mechanisms are based on domestic law; at the level of EEA law, only liability for incorrect implementation of EEA law exists as a back-up sanctioning mechanism for EFTA EEA citizens. In practice, State liability may have led to 'de facto' homogeneity in combination with the other provisions, leaving direct effect as a more theoretical than real problem. ${ }^{81}$ Still, the 'distinct legal order of its own' proves to be dependent on domestic law and implementing measures. As such it is similar to general international law and displays a considerably lower degree of autonomy than EU law. ${ }^{82}$

\footnotetext{
78 EFTA Court 10 December 1998, Case E-9/97 Erla María Sveinbjörnsdóttir v Iceland, para 58.

79 Sveinbjörnsdóttir $v$ Iceland, above n 78, para 59 (italics in original). See also EFTA Court 3 October 2007, Case E-1/07 Criminal proceedings against A, para 37.

80 Sveinbjörnsdóttir v Iceland, above n 78, para 60.

81 Fredriksen, above n 18, pp 490-1.

82 Even the concept of State liability for erroneous implementation was not unanimously accepted at the domestic level in EFTA EEA Member States. In Iceland, sceptical commentators criticized the decision, while the courts granted compensation for erroneous implementation. In Norway, the well-known Finanger controversy required lengthy litigation to reach an agreement on the issue of State responsibility of Norway for incorrect implementation of the Motor Vehicle Insurance Directives. Norwegian law had stated that a passenger who had suffered an injury after having accepted a ride with a drunk driver was precluded from compensation if he or she knew or must have known that the driver was under the influence of alcohol; only after an advisory opinion given by the EFTA Court in Finanger $I$ and conflicting views among the Norwegian courts of lower instance, did the Norwegian Supreme Court finally decide in 2005 to grant compensation to Veronika Finanger in Finanger II; see on this case-law Örlygsson, above n 16, pp 239-40.
} 


\section{The Autonomous Interpretation of EEA Law: The EFTA Court and its Relationship with the CJEU and Domestic Courts}

The effect of EEA law is thus closely tied to national law. Another central feature of the autonomy of EU law is its uniform interpretation ensured by the authority of the CJEU. In EEA law, there are two main differences from the situation in EU law. First, the interpretative authority of the EFTA Court over EEA law vis-à-vis the domestic courts is not as clear as in the case of the CJEU because of the weaknesses of the advisory opinion procedure. Secondly, there is controversy, given the principle of homogeneity as it is enshrined in EEA law, on whether the EFTA Court is an independent court or effectively subject in last instance to the authority of the CJEU.

\section{(i) The EFTA Court and Domestic Courts}

On the first question, no requirement is imposed on domestic courts to submit questions on the interpretation of EEA law to the EFTA Court, nor is the answer to such questions binding. EFTA EEA States can even influence the procedure for referring questions to the EFTA Court through their domestic law. ${ }^{83}$

The case-law at the domestic level, at least partly, gives only limited room to requests for advisory opinions. In Iceland, the Supreme Court refused to request an opinion on the interpretation of EEA law-based rules because the relevant rules had already been incorporated into Icelandic law. A district court furthermore did not request an opinion because it found that review of a law against the benchmark of the Constitution could not be influenced by an interpretation of EEA law given by the EFTA Court. ${ }^{84}$

By contrast, domestic courts gradually accepted a sort of persuasive authority of the EFTA Court's interpretation of EEA law. The Icelandic Supreme Court held on the authority of advisory opinions that, based on the duty of cooperation under Article 3 EEA Agreement, Icelandic courts were required to 'take account' of an advisory opinion of the EFTA Court in their interpretation of EEA law and should only deviate from the Court's view if 'specific reasons'

\footnotetext{
${ }^{83}$ In Iceland, if a request is first referred to the Supreme Court by a district court, the pertinent domestic legislation even seems to enable the Supreme Court to amend or strike down the request, Björgvinsson, above n 15, p 40. By contrast, in Norway no higher instance court can strike down a request for an advisory opinion by a lower court, Örlygsson, above n 16, p 232. Also, the EFTA Court seems to be applying increasingly intrusive scrutiny to restrictions of requests for advisory opinions, see the case of the Icelandic Supreme Court in EFTA Court 28 September 2012, Case E-18/11 Irish Bank Resolution Corporation Ltd v Kauping hf, paras 53ff. By comparison, in EU law the CJEU emphasized that based on the full effect of primacy, national courts must be completely free under national law to decide for themselves when to submit questions and what questions to ask in the framework of a preliminary ruling procedure, see CJEU 22 June 2010, Joined Cases C-188/10 and C-189/10 Aziz Melki and Sélim Abdeli, para 52.

${ }^{84}$ See, sceptical on both cases, Björgvinsson, above n 15, pp 45-8.
} 
could be advanced. ${ }^{85}$ A similar solution was embraced by the Norwegian Supreme Court, which held in Finanger I that the EFTA Court seemed better placed to interpret the EEA Agreement, as seemed also to have been accepted by the Norwegian legislature when agreeing to the obligations under EEA law, and that court's views should thus be given 'pre-eminent or considerable weight'. ${ }^{86}$ In later case-law, the Supreme Court repeated that there had to be 'good reasons' for it to deviate from an interpretation given by the EFTA Court. ${ }^{87}$

Thus, EFTA EEA States' courts developed models in their case-law to ensure that appropriate weight is being given to EFTA Court decisions. Despite the explicitly non-binding effect of advisory opinions, such opinions are effectively respected by domestic courts. This 'softer'88 authority may be comparable to the authority of decisions of international courts whose rulings also typically do not enjoy formal power in a domestic legal order comparable to national judicial decisions; but such decisions at the same time cannot easily be brushed aside and ignored by domestic courts. ${ }^{89}$

Summing up, while the CJEU's interpretative authority is absolute, the authority of the EFTA Court weighs less heavily on domestic courts; if they want-and have good reasons - they can still deviate from the EFTA Court's opinion. Still, the EFTA Court exercises interpretative authority over EEA law and is not irrelevant for or subject to domestic courts.

\section{(ii) The EFTA Court and the CJEU}

The independence and interpretative authority of the EFTA Court is also sometimes put in doubt because of the special relationship that the principle of homogeneity in EEA law creates between the EFTA Court and the CJEU. There is debate over whether the EEA Agreement actually provides for legal pluralism, ie whether it accepts divergent interpretations from EU law for identical norms, or whether homogeneity requires that at the end of the day, the CJEU's reading of EU law must be the supreme authority; in the latter case the EFTA Court could be considered as hierarchically inferior to the CJEU.

In the doctrine, some observed that the EEA Agreement indeed should be seen as a case of legal pluralism, in the sense that the EFTA Court can accommodate the features of legal traditions such as the Norwegian one in its case-law. ${ }^{90}$ This idea, however, not only seems hardly supported in the case-law

\footnotetext{
85 Björgvinsson, above n 15, p 41. See also Örlygsson, above n 16, p 234.

86 Örlygsson, above n 16, p 235.

87 Örlygsson, above n 16, p 235.

${ }^{88}$ HP Graver, 'Die Ausdehnung des Europäischen Gemeinschaftsrechts auf Nichtmitglieder der Union - Das Beispiel Norwegens' in P-C Müller-Graff (ed.), Europäisches Integrationsrecht im Querschnitt (Nomos, 2003), p 45 at p 57.

89 Bernitz, above n 3, p 34.

90 See with a discussion of the pertinent case-law T-I Harbo, 'The European Economic Area Agreement: A Case of Legal Pluralism’ (2009) 78 Nordic Journal of International Law 201.
} 
of the EFTA Court, it is also difficult to reconcile with the overall objective of homogeneity. ${ }^{91}$

By contrast, the objective of homogeneity is taken by some to mean that there is effectively a hierarchical superiority of the CJEU over the EFTA Court as regards the interpretation of EEA law-if not 'de jure', then at least 'de facto'. ${ }^{22}$ Based on a mere observation of the legal texts, no clear answer emerges as to hierarchy. Homogeneity is a two-way street: the CJEU also seems to acknowledge that it should take into account case-law of the EFTA Court, although there is no formal obligation to this effect in EEA or EU law. ${ }^{93}$ A disagreement on the interpretation of EEA rules knows no final arbiter based on the EEA Agreement: The procedure of Article 111(3) EEA Agreement for the settlement of disputes enables the Contracting Parties to refer a question to the CJEU. Yet, this only happens with the agreement of the parties, and the legal force of the answer given by the CJEU is not clarified. Controversy might simply continue. A strong argument in favour of the claim that the EFTA Court must necessarily possess independent interpretative authority over EEA law can be derived from the procedure under Article 105(2) and (3) EEA Agreement. This procedure provides for the constant review of the development of case-law of both courts by the EEA Joint Committee and discussion of divergences, which only makes sense if legal value of its own is attributed to the EFTA Court's case-law. ${ }^{94}$

The written law thus provides no conclusive answer, but only some elements in favour of autonomous interpretative authority of the EFTA Court. Recent case-law, however, re-ignited scepticism on this authority. In L'Oréal Norge, the EFTA Court reversed with a somewhat terse reasoning its older case-law in order to follow a different interpretation for a substantially identical norm which the CJEU had embraced in the meantime. ${ }^{95}$ The EFTA Court's decision was received as the end of any pluralistic vision, showing that there could be no coexistence between the ideas of institutional equality of the two courts and homogeneity of interpretation as the overarching goal of the EEA Agreement. ${ }^{96}$ Following up on earlier writings which had already suggested that domestic

${ }^{91}$ Fredriksen, above n 18, p 493.

92 Fredriksen, above n 18, p 499.

93 See on this judicial dialogue between the two courts already Section IV.A.

${ }^{4}$ S Magnússon, 'Judicial Homogeneity in the European Economic Area and the Authority of the EFTA Court - Some Remarks on an Article by Halvard Haukeland Fredriksen' (2011) 80 Nordic Journal of International Law 507 at 512.

95 EFTA Court 8 July 2008, Case E-9/07 and 10/07 L'Oréal Norge AS v Per Aarskog AS, Nille AS and Smart Club AS. The EFTA Court in this case reversed its holding in EFTA Court 3 December 1997, Case E-2/97 Mag Instruments Inc. and California Trading Company Norway, Ulsteen on the international exhaustion of trade-mark rights to follow the CJEU's position in favour of regional exhaustion established in CJEU 16 July 1998, Case C-355/96 Silhouette International Schmied v Hartlauer Handelsgesellschaft. See for a detailed commentary of the case-law B Pirker, 'Interpreting Multi-Sourced Equivalent Norms: Judicial Borrowing in International Courts' in T Broude and Y Shany (eds), Multi-Sourced Equivalent Norms in International Law (Hart Publishing, 2011), p 93 at pp 101-6.

${ }_{96}$ Fredriksen, above n 18, p 496. 
courts should look to the case-law of the CJEU rather than to that of the EFTA Court for the true interpretation of EEA rules, ${ }^{97}$ a commentator suggested that the EFTA Court's judgments could be seen as vested with only 'provisional authority pending a decision' of the CJEU. ${ }^{98}$

There is an undeniable tilt in the setting of two courts to interpret EEA law in favour of the CJEU. However, the case of a 'de facto' interpretative authority which would virtually render the EFTA Court obsolete is not as clear by far as suggested by the reactions to the L'Oréal Norge case. As a starting point, there are a number of situations where the EFTA Court is not interpreting substantially identical norms to EU law and its authority is thus beyond dispute. ${ }^{99}$ Even when both courts are interpreting the same provision of EEA law, the creation of two independent courts would be obsolete if one was always obliged to follow the other. There is thus leeway for divergent interpretations; this potential to disagree is vital to counter an absolute understanding of homogeneity and posits the interpretative authority of the EFTA Court - as limited as it may be because of the objective of homogeneity - as a procedural safeguard for the EFTA EEA States, ${ }^{100}$ which after all concluded the EEA Agreement with the intention of not subjecting their courts to the CJEU. ${ }^{101}$ Such a safeguard model is not new; a variety of domestic constitutional courts in EU Member States in the past only accepted the authority of EU law and the CJEU while reserving the exercise of their own powers of judicial review, ie their powers to disagree. ${ }^{102}$

A close reading of the actual decision in L'Oréal Norge supports this conclusion. Finding it an 'inherent consequence' of the EEA system that the two courts could come to different interpretations, the EFTA Court first held that the situation of CJEU case-law overruling its own findings in earlier case-law called for 'an interpretation of EEA law in line with new case law of the [CJEU] regardless of whether the EFTA Court has previously ruled on the question'. ${ }^{103}$ Then, however, the EFTA Court did not automatically follow the newer case-law, but looked for 'compelling grounds' in the form of 'differences in scope and purpose' between EU law and EEA law. ${ }^{104}$ Only because

\footnotetext{
97 See eg Graver, above n 88, p 57. See also the doctrinal opinion in Norway cited in Fredriksen, above n 18, p 498 fn 73.

98 T van Stiphout, 'The L'Oréal Cases - Some Thoughts on the Role of the EFTA Court in the EEA Legal Framework: Because it is worth it!' (2009) Jus \& News 7 at 15.

${ }^{99}$ Magnússon, above n 94, p 516.

100 Magnússon, above n 94, p 514.

101 This opinion appears to be still relevant. The EEA Agreement would enable EFTA EEA Members to create procedures to refer questions on the interpretation of the EEA Agreement to the CJEU (Art 107 EEA Agreement and Protocol 34), but none of the States has done so, see Fredriksen, above n 18, p 487.

102 See eg with further references Z Kühn, 'Wachauf and ERT: On the Road from the Centralised to the Decentralised System of Judicial Review' in MP Maduro and L Azoulai (eds), The Past and Future of EU Law - The Classics of EU Law Revisited on the 50th Anniversary of the Rome Treaty (Hart Publishing, 2010), p 151 at p 161 and fn 104.

103 L'Oréal Norge v Per Aarskog and others, above n 95, paras 28-29.

${ }^{104}$ L'Oréal Norge $v$ Per Aarskog and others, above n 95, para 31.
} 
there were no such grounds, the weighing of arguments of the CJEU was adopted by the EFTA Court based on the principle of homogeneity, which led to the reversal of its older case-law.

Summing up, the EFTA Court may be limited in its autonomy of interpretation through the objective of homogeneity. Neither in written EEA law nor in the interpretative approach chosen by the EFTA Court, however, is there an absolute, trumping version of homogeneity or a full-scale submission of the EFTA Court to the CJEU.

\section{Conclusion}

EEA law features a legal order 'distinct' from others in the eyes of the EFTA Court. This conclusion is bolstered by the findings of this section. At the same time, however, it must be noted that for the question of constitutionalization, this legal order is characterized by a remarkably lower degree of autonomy in several senses. The quasi-legislative process of decision-making as to the adaptation of EEA law to new developments in EU internal market law gives virtually no role to directly elected institutions and even represents the views of the EFTA EEA States' governments only in aggregate. The legal order itself depends much more on implementation by domestic law than by EU law. Claims that the EFTA Court possesses no autonomous interpretative authority over the EEA Agreement have, however, been shown to be exaggerated. There is thus again some autonomy, though more limited through the operation of the objective of homogeneity. Summing up, it appears difficult to speak of a constitutional regime in institutional terms if this qualification is already disputed for the much more autonomous legal order of EU law.

\section{Conclusion}

Our examination has indeed discovered a number of constitutional functions in EEA substantive law. EEA law allocates power in the sense that it restricts regulatory powers for the benefit of economic integration similar to the EU internal market. In EEA law, fundamental rights are protected. EEA citizens enjoy a right to move and reside freely comparable to EU citizens. However, the notion of autonomy puts this first sketch in perspective. At the institutional level, the EEA decision-making process features a very low degree of representativeness for citizens of EFTA EEA States. The legal order of EEA law is much more dependent on implementation through domestic law. The EFTA Court as the interpreter of EEA law is not as authoritative in its relationship with domestic courts of the EFTA EEA States as the CJEU with courts of the EU Member States, and it is limited in its interpretative freedom by the principle of homogeneity which favours solutions following the CJEU's case-law. 
The single constitutional elements identified in EEA substantive law stem most prominently from the legal transfusion from EU law to EEA law under the principle of homogeneity. However, the EFTA Court's interpretative efforts-as laudable and fruitful as they may seem in cases like Clauder-cannot fully cure the systemic incompleteness of the EEA Agreement and truly render it a constitutional regime. The EEA's trade-off between the competing objectives of partial and homogeneous integration into the EU internal market and the preservation of some prerogatives of domestic sovereignty comes at the price of a lower degree of autonomy of EEA law in comparison to EU law. In terms of the constitutionalization of EEA law, the EFTA Court may be mixing things well, but to us, a separate taste of each, oil and vinegar, is still discernible. 
Reproduced with permission of the copyright owner. Further reproduction prohibited without permission. 